\title{
Whatsapp Stories Sebagai Media Komunikasi Self Disclosure (Studi pada Mahasiswa Fakultas Ushuluddin Adab dan Dakwah IAIN Ponorogo Tahun Angkatan 2017)
}

\author{
Berliana Huaida \\ Institut Agama Islam Negeri Ponorogo \\ huaidaberliana@gmail.com
}

\begin{abstract}
Basically, in today's era, there are so many individuals using social media. Lots of people use social media as a medium for self-disclosure. Self-disclosure, which is an activity to share thoughts and feelings with others, is closely related to social media intermediaries which can reach the public at large and simultaneously. One example of social media that is widely used is whatsapp stories. In the whatsapp stories, some of the students of the Faculty of Ushuluddin Adab and Da'wah of IAIN Ponorogo for the year 2017 carried out self-disclosure, and whatsapp was the public scope, meaning that the openness that was carried out could be shared and consumed by many people. For this reason, it is necessary to know the forms and effects of the openness carried out by the Faculty of Ushuluddin Adab and Da'wah IAIN Ponorogo Students Year 2017.

This research focuses on whatsapp stories as a medium of self-disclosure communication. To describe the focus of this research in depth, this study uses descriptive qualitative research methods with the Johari Window Self Disclosure theory.

Based on the results of the research, it has been found: First, the form of self-disclosure for the students of the Faculty of Ushuluddin Adab and Da'wah at IAIN Ponorogo for the year 2017 is open, blind, and closed. Second, the effects arising from self-disclosure are in the form of positive effects and negative effects. The positive effect is to achieve satisfaction, the response of others to determine self-change, and other people's posts open up one's mind. Meanwhile, the negative effect is that if you cannot control the use, you will get a negative response from other people, not gain trust, and get losses.
\end{abstract}

Keywords: Communication, Self Disclosure, Johari Window, Whatsapp Stories, Students

\begin{abstract}
Abstrak
Pada dasarnya di era sekarang ini terlihat begitu banyak individu yang menggunakan media sosial. Banyak sekali yang memanfaatkan media sosial sebagai media self disclosure (Pengungkapan diri). Self Disclosure yang merupakan kegiatan berbagi suatu pemikiran dan rasa dengan orang lain ini berkaitan erat dengan perantara media sosial yang mana dapat menjangkau publik secara luas dan bersamaan. Salah satu contoh media sosial yang banyak sekali digunakan adalah whatsapp stories. Di dalam whatsapp stories itulah sebagian Mahasiswa Fakultas Ushuluddin Adab dan Dakwah IAIN Ponorogo Tahun Angkatan 2017 melakukan pengungkapan diri, dan whatsapp merupakan ruang lingkup publik, berarti keterbukaan yang dilakukan dapat dibagikan dan dikonsumsi oleh banyak orang. Untuk itu perlu diketahui bagaimana bentuk dan
\end{abstract}


Whatsapp Stories Sebagai Media Komunikasi Self Disclosure (Studi pada Mahasiswa Fakultas Ushuluddin Adab dan Dakwah IAIN Ponorogo Tahun Angkatan 2017)

Berliana Huaida

efek dari keterbukaan yang dilakukan oleh Mahasiswa Fakultas Ushuluddin Adab dan Dakwah IAIN Ponorogo Tahun Angkatan 2017.

Penelitian ini berfokus pada whatsapp stories sebagai media komunikasi self disclosure. Untuk menjabarkan focus penelitian tersebut secara mendalam, dalam penelitian ini menggunakan metode penelitian kualitatif deskriptif dengan teori Self Disclosure Johari Window.

Berdasarkan hasil penelitian, telah ditemukan: Pertama, bentuk self disclosure Mahasiswa Fakultas Ushuluddin Adab dan Dakwah IAIN Ponorogo Tahun Angkatan 2017 adalah terbuka, buta, dan tertutup. Kedua, efek yang ditimbulkan dari self disclosure yaitu berupa efek positif dan efek negatif. Efek positifnya adalah mencapai kepuasan, respon orang lain menentukan perubahan diri, dan postingan orang lain membuka pikiran diri. Sedangkan untuk efek negatifnya adalah apabila tidak dapat mengontrol penggunaan maka akan mendapatkan respon negatif dari orang lain, tidak mendapatkan kepercayaan, dan mendapatkan kerugian.

\section{Kata Kunci: Komunikasi, Self Disclosure, Johari Window, Whatsapp Stories, Mahasiswa PENDAHULUAN}

Manusia sejatinya adalah mahluk sosial yang tidak bisa hidup sendiri tanpa manusia lain. Tidak bisa terlepas dari interaksinya dengan sesama. Maka dari itu terbentuklah proses sosial. Manusia dan interaksi sosial adalah satu kesatuan. Manusia ingin mengetahui apa yang ada disekitarnya, bahkan ingin mengetahui hal-hal yang terjadi dalam dirinya dimana rasa ingin tahu ini memaksa manusia untuk berkomunikasi.

Komunikasi merupakan proses untuk menyatakan pertanyaan antar individu, yaitu pikiran atau perasaan individu kepada individu lain dengan menggunakan bahasa sebagai alat penyalurnya. (Yusuf Zainal Abidin, 2015). Dengan komunikasi ini manusia mampu bertukar berbagai macam pemikiran dan rasa mengenai dirinya dengan orang lain, dimana hal ini berkaitan dengan pengungkapan diri (self disclosure). Pengungkapan diri (self disclosure) yang merupakan kegiatan berbagi suatu pemikiran dan rasa dengan orang lain ini berkaitan erat dengan perantara media sosial yang mana dapat menjangkau publik secara luas dan bersamaan.

Media sosial sekarang ini menjadi salah satukebutuhan primer yang digunakan oleh seluruh orang di dunia (Laili Humam Miftahudin, 2018). Media sosial adalah sebuah media daring, dimana para penggunanya dapat dengan mudah berpartisipasi, berbagi, dan menciptakan 62 
laman jejaring sosial. Media sosial menggunakan teknologi berbasis aplikasi atau website yang dapat mengubah suatu komunikasi kedalam bentuk dialog interaktif. Membahas tentang aplikasi, kini telah hadir satu aplikasi yang mana banyak digunakan orang-orang di seluruh dunia yaitu WhatsApp Massanger.

WhatsApp Massanger merupakan aplikasi pesan instan untuk smartphone yang didirikan pada tahun 2009. Jika dilihat dari cara kerjanya, whatsapp ini hampir sama dengan pengirim pesan SMS (Short Massage Service). Perbedaanya jika whatsapp tidak menggunakan pulsa melainkan data internet.

Lebih dari 1 miliar orang di lebih dari 180 negara menggunakan whatsapp untuk terhubung dengan teman dan keluarga, kapan saja dan dimana saja. WhatsApp ini adalah aplikasi gratis dan menawarkan kemampuan mengirim pesan dan melakukan panggilan yang aman, fleksibel, sederhana, dan reliabel yang tersedia di seluruh dunia. WhatsApp mendukung untuk mengirim dan menerima berbagai macam media, seperti teks, foto, video, audio, dokumen, lokasi, panggilan suara, juga panggilan video.

WhatsApp kini menawarkan fitur whatsapp stories atau yang lebih sering disebut status whatsapp dimana pengguna dapat memposting gambar atau video sebagai status di whatsapp. Dapat dilihat oleh kontak yang disimpan dan orang yang menyimpan nomor kontak kita. WhatsApp Stories ini dapat dimanfaatkan untuk berbagi ide-ide pemikiran, ekspresi diri (self expression), pencitraan diri (personal branding), ajang curhat untuk berkeluh kesah dan lain-lain yang bisa kita bagikan kepada teman-taman.

Pada sekarang ini, meskipun seseorang sudah saling kenal tetapi masih saja belum tentu memahami karakter orang lain. Untuk itu, seseorang lebih senang dan nyaman jika mengungkapkan diri melalui media sosial baik dalam hal umum maupun pribadi. Pada umumnya, seseorang akan lebih nyaman jika mengungkapkan diri dengan orang yang sudah dekat dan 
Whatsapp Stories Sebagai Media Komunikasi Self Disclosure (Studi pada Mahasiswa Fakultas Ushuluddin Adab dan Dakwah IAIN Ponorogo Tahun Angkatan 2017)

Berliana Huaida

dipercaya. Namun kebanyakan pada masa sekarang seseorang lebih mudah menyalurkan emosinya melalui media sosial seperti whatsapp stories untuk sekedar meredakan pemikirannya dari pada langsung mengatakan kepada seseorang.

Maka dari itu, peneliti mengambil kesimpulan untuk memunculkan topik mengenai Penggunaan whatsapp stories sebagai media komunikasi yang bertujuan untuk melihat bagaimana perkembangan self disclosure bagi setiap individu, dengan judul sebagai berikut:

“Whatsapp Stories Sebagai Media Komunikasi Self Disclosure (Studi Pada Mahasiswa Fakultas Ushuluddin Adab dan Dakwah IAIN Ponorogo Tahun Angkatan 2017)"

\section{METODE PENELITIAN}

Dalam penelitian ini, peneliti menggunakan metode kualitatif deskriptif. Data deskriptif mengandaikan bahwa data tersebut berupa sebuah teks. Metode ini menekankan pada proses. Proses berarti melihat bagaimana realita, fakta, gejala dan suatu peristiwa itu terjadi dan dialami. (Conny R. Semiawan, 2010).

Berdasarkan sumbernya, data penelitian digolongkan menjadi dua bagian yaitu data primer dan data sekunder.

a. Data primer dari penelitian adalah data hasil wawancara dengan responden Mahasiswa Fakultas Ushuluddin Adab dan Dakwah IAIN Ponorogo Tahun Angkatan 2017 yang kemudian bentuk komunikasi tersebut selanjutnya dianalisis sesuai dengan teori Johari Window.

b. Data sekunder merupakan sumber data pendukung dari suatu penelitian untuk melengkapi sumber data utama. Data sekunder dalam penelitian ini berupa hasil dari screenshot (tangkapan gambar layar) stories dari setiap mahasiswa dan data buku-buku referensi, karya ilmiah yang berkaitan dengan penelitian, dokumentasi serta beberapa situs internet yang dapat membantu keabsahan data penelitian. 
Dalam Analisis model Miles and Huberman, Analisis data kualitatif ini berlangsung selama proses pengumpulan data dan selesai pengumpulan data dalam periode tertentu. Dilakukan secara terus-menerus sampai tuntas.

Teknik pemeriksaan keabsahan data penelitian ini menggunakan teknik trianggulasi. Trianggulasi merupakan teknik pemeriksaan keabsahan data dengan memanfaatkan sumber lain sebagai pembanding data itu. Teknik trianggulasi yang digunakan dalam penelitian ini adalah trianggulasi sumber yang berarti membandingkan dan mengecek data yang telah diperoleh. (Conny R. Semiawan, 2010).

Obyek dalam penelitian ini adalah Self Diclosure pada media social Whatsapp melaui fitur whatsapp stories. Data yang didapatkan berasal dari subyek yang telah dipilih. Data tersebut kemudian akan diteliti kembali kebenarannya dengan menggunakan teknik trianggulasi sumber. Dimana data yang diperoleh dari hasil wawancara akan dibandingkan dengan hasil observasi dan data dari studi dokumen yang dilakukan oleh peneliti.

\section{HASIL PENELITIAN DAN PEMBAHASAN}

\section{A. Bentuk Komunikasi Self Disclosure Melalui Whatsapp Stories Yang Ditunjukkan Oleh Mahasiswa Fakultas Ushuluddin Adab dan Dakwah IAIN Ponorogo Tahun Angkatan 2017}

Setiap orang pasti mempunyai keinginan dan cita-cita terbesar dalam hidupnya, salah satunya adalah keinginan agar diakui oleh orang lain. Pengakuan atas dasar capaian yang hendak didapat. Teknologi kini menjadi akses bagi siapa saja yang ingin sukses. Mempermudah seseorang untuk mencapai tujuan yang ingin dicapai, mendekatkan apa yang hendak diraih. Karena itu, muncullah berbagai fenomena dalam media sosial salah satunya self disclosure melalui whatsapp stories. 
Whatsapp Stories Sebagai Media Komunikasi Self Disclosure (Studi pada Mahasiswa Fakultas Ushuluddin Adab dan Dakwah IAIN Ponorogo Tahun Angkatan 2017)

Berliana Huaida

Self disclosure yang ditampilkan oleh Mahasiswa Fakultas Ushuluddin Adab dan Dakwah IAIN Ponorogo Tahun Angkatan 2017 beragam dan tentunya memiliki latar belakang atau tujuan berbeda yang mendasari adanya keterbukaan tersebut.

Dapat diketahui bahwa sebagian responden menggunakan fitur whatsapp stories sebagai sebuah media bisnis/berjualan, mereka memanfaatkan fitur ini untuk mereka berpromosi, menginformasikan sebuah hasil usaha yang mereka perjual belikan. Gambaran ini diperlihatkkan oleh Kurniasari, Umi, Novia, Uli, dan Khansa, dan ada beberapa lagi namun tidak se-aktif mereka.

Ada juga yang memanfaatkan media ini sebagai media brading diri, mereka ingin membentuk sebuah citra diri. Ingin memberitahukan orang lain bahwa dirinya bisa melakukan dan menghasilkan sesuatu. Selain itu ada juga yang memanfaatkan fitur ini sebagai media untuk berbagi kesenangan atau hobi. Gambaran ini diperlihatkan oleh Dine, Alvin, Muiz, Anggo, dan ada beberapa lagi namun tidak se-terlihat mereka dalam membranding diri dan membagikan hobi nya.

Tak terlepas dari pemikiran, responden pun menggunakan fitur ini sebagai media kritik terhadap seseorang atau lembaga. Terkadang seseorang tidak mampu jika harus mengutarakannya pemikirannya secara langsung, untuk itu bisa menggunakan fitur ini sebagai perantaranya agar di dengar oleh yang lain. Gambaran ini sebenarnya terlihat pada seluruh respon namun yang paling kentara adalah Shodik dan Umi.

Yang paling standart adalah seluruh responden pasti menggunakannya untuk membagikan kegiatan sehari-hari. Begitupun dengan informasi yang menyertainya, seluruh responden memanfaatkan fitur ini sebagai media bertukar informasi, mengutarakan apa yang ada di dalam pemikirannya, dan bahkan berkeluh kesah, jadi gambaran ini dapat dilihat dari seluruh responden walaupun ada rentang intensitas waktu dalam mengungkapkannya. 
1. Teori Johari Window

Self Disclosure dapat diartikan sebagai kegiatan yang dilakukan oleh individu dengan cara berbagi, menceritakan, memberikan informasi tentang dirinya kepada orang lain yang sebelumnya mungkin belum pernah diketahui.

Teori yang pertama kali diperkenalkan oleh Joseph Luth dan Harry Ingham (Psikolog Amerika) pada tahun 1955 yang dikenal dengan nama Jendela Johari atau Johari Window yang mencerminkan adanya suatu proses memberi dan menerima, baik berupa informasi, kritikan, pujian dari orang lain untuk kepentingan pengembangan diri. (Paulus Kurniawan, 2017).

Luth dan Ingham menyatakan sebuah asumsi-asumsi mengenai self disclosure, yaitu dalam suatu lingkup masyarakat atau organisasi apabila antar anggota saling mengenal maka komunikasi dalam lingkungan akan semakin efektif, dan semakin seseorang terbuka serta jujur dalam berinteraksi dengan orang lain maka semakin bagus kualitas hubungan orang tersebut. (Paulus Kurniawan, 2017).

Jendela Johari banyak dimanfaatkan sebagai pelatihan kesadaran diri, peningkatan personal dan komunikasi. Mengarah pada diri sendiri sebagai subjek dan orang lain sebagai objek lain dari kelompok pribadi. Dalam pelatihan, feedback merupakan aspek terpenting dalam proses memberi dan menerima. Melalui feedback tersebut seseorang bisa melihat dan mengenal orang lain. Orang lain juga dapat mempelajari bagaimana pandangan kita terhadap dirinya.

Dalam konteks keterbukaan yang dilakukan responden Mahasiswa Fakultas Ushuluddin Adab dan Dakwah IAIN Ponorogo Tahun Angkatan 2017 jika dikaitkan dengan teori Johari Window tergambar sebagai berikut: 
Whatsapp Stories Sebagai Media Komunikasi Self Disclosure (Studi pada Mahasiswa Fakultas Ushuluddin Adab dan Dakwah IAIN Ponorogo Tahun Angkatan 2017)

Berliana Huaida

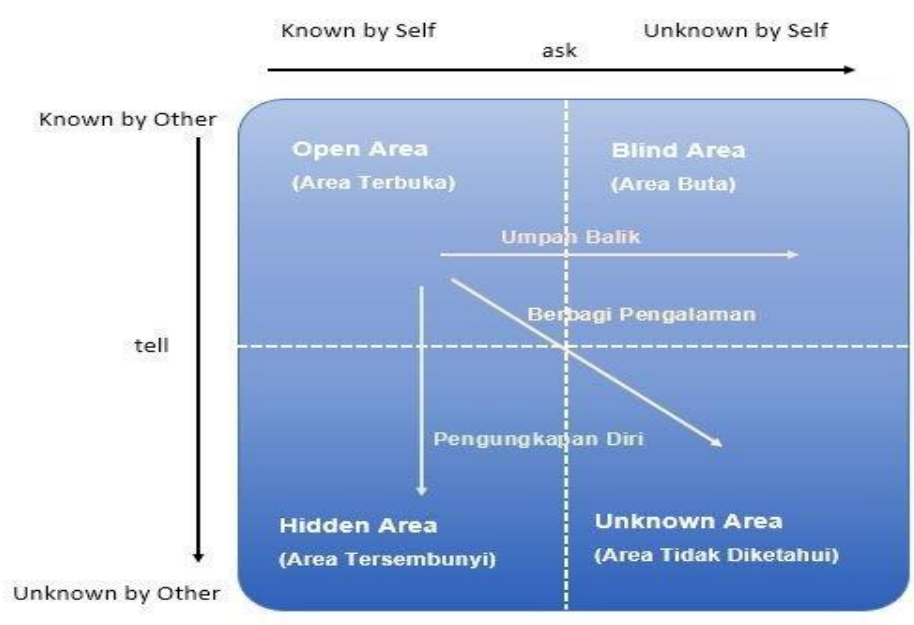

Gambar 4.1

Teori Johari Window

a. Daerah Terbuka

Di dalam diri seseorang terdapat daerah terbuka yaitu bagian dari diri yang menyajikan semua informasi, sifat, perilaku, keinginan, perasaan, motivasi, gagasan dan ide yang diketahui oleh diri sendiri dan orang lain. Konsep jendela ini yaitu seseorang dapat mengenal dengan baik seperti apa dirinya begitupun orang lain. Jika dilihat dari keterbukaan yang dilakukan oleh responden, yang terjadi adalah individu terbuka akan informasi pribadi dan setiap momen yang dianggapnya penting, mereka terbuka akan apa yang perlu dan sekiranya harus diketahui oleh orang lain, dengan mudah membagikan perasaannya namun tetap dengan batas sewajarnya.

Dan disini hanya Dine yang tidak membagikan informasi pribadi namun untuk momen, emosi/perasaan pernah. Sementara Kurniasari, Alvin, Novia, dan Anggo tidak membagikan emosi/perasaan namun untuk informasi pribadi dan momen pernah membagikannya. Selebihnya untuk responden lain melakukan semua dari konsep yang sudah ditentukan oleh peneliti mengenai daerah terbuka ini. 
Keterbukaan yang dimaksudkan memang bersifat pribadi namun tidak masalah untuk menjadi rahasia umum. Jadi, seluruh responden telah memperlebar daerah terbuka dan mempersempit daerah tertutup.

Komunikasi tergantung pada tingkat keterbukaan dimana seseorang membuka dirinya untuk orang lain dan dirinya sendiri. Jika tidak ada keterbukaan yang terjadi maka akan semakin kecil bagian daerah terbuka dan akan semakin buruk komunikasi yang berlangsung. Untuk itu perlu meningkatkan komunikasi dengan memperlebar daerah terbuka.

b. Daerah Buta

Dalam jendela daerah buta, segala aspek yang ada dalam diri diketahui oleh orang lain namun tidak disadari dan diketahui oleh diri sendiri. Jendela ini biasanya menyangkut informasi tentang diri sendiri yang selama ini dipilih untuk diabaikan. Karena adanya daerah buta ini membuat komunikasi menjadi tidak efektif, maka dengan mencari atau mendapatkan feedback, kritikan, masukan dari orang lain, seharusnya bisa mengurangi gejala pada jendela daerah ini dan dapat memperlebar jendela daerah terbuka yang notabenenya adalah untuk meningkatkan kesadaran diri.

Dalam konteks yang telah dilakukan peneliti terhadap responden, seluruhnya terlihat bersifat terbuka. Keterbukaan yang mereka tampilkan mendapatkan respon dan feedback dari orang lain. Seluruh responden berhasil mempersempit Jendela daerah buta dan memperlebar daerah terbuka.

c. Daerah Tertutup

Segala aspek dalam diri yang disadari oleh diri sendiri, dan secara sadar ditutupi atau disembunyikan dari orang lain. Daerah ini berisi tentang apa-apa yang 
Whatsapp Stories Sebagai Media Komunikasi Self Disclosure (Studi pada Mahasiswa Fakultas Ushuluddin Adab dan Dakwah IAIN Ponorogo Tahun Angkatan 2017)

Berliana Huaida

diketahui oleh diri sendiri atau orang lain dan sengaja disimpan untuk diri sendiri dan orang lain tidak mengetahuinya.

Jika dalam konteks yang telah dilakukan peneliti terhadap responden, ada beberapa yang menutup dan mempertahankan besarnya daerah ini seperti Kurniasari, Lina, Dine, Alvin, Novia, Uli, Zakiya, Shodik, Hamdan, Anggo, dan Khansa. Mereka menjelaskan bahwa ada beberapa hal yang tidak perlu diperlihatkan dan ditampilkan secara keseluruhan kepada publik, karena ada beberapa hal yang begitu penting dan tidak seharusnya banyak yang mengetahui, ada yang menjawab bahwa apa yang disimpan itu adalah sebuah aib untuk itu tidak perlu diperlihatkan.

Namun ada juga beberapa responden yang bisa mempersempit daerah tertutup ini seperti yang dilakukan oleh Umi, Muiz, dan Maifir. Mereka menjelaskan bahwa perlu juga melihat bagaimana penilaian orang lain terhadap diri tetapi masih pada tahap yang sewajarnya. Jadi, dalam jendela daerah tertutup akan tetap pada posisinya dan hanya dipersempit beberapa oleh daerah terbuka oleh mereka bertiga.

d. Daerah Gelap

Daerah ini adalah daerah paling kritis, bagian diri yang tidak dikenal diri sendiri dan orang lain. Seseorang akan mengetahui aspek dari diri ini yang tidak dikenal melalui kondisi tertentu, misalnya melalui setelah melakukan observasi diri.

Dalam konteks yang telah dilakukan peneliti terhadap responden, seluruhnya belum pernah merasa dan mengetahui tentang daerah ini, meskipun pernah mungkin ia tidak menyadari bahwa daerah inilah yang telah diperlihatkan, bahkan bisa jadi seseorang akan lebih nyaman mengungkapkannya secara langsung dan pribadi kepada seseorang daripada harus mengungkapkannya kepada publik.

2. Temuan dengan Teori Johari Window 
Jika digambarkan melalui empat Jendela Johari dimana jendela tersebut dapat bergeser sesuai dengan keterbukaan yang ditampilkan. Maka keterbukaan diri atau Self Disclosure Mahasiswa Fakultas Ushuluddin Adab dan Dakwah IAIN Ponorogo Tahun Angkatan 2017 adalah sebagai berikut:

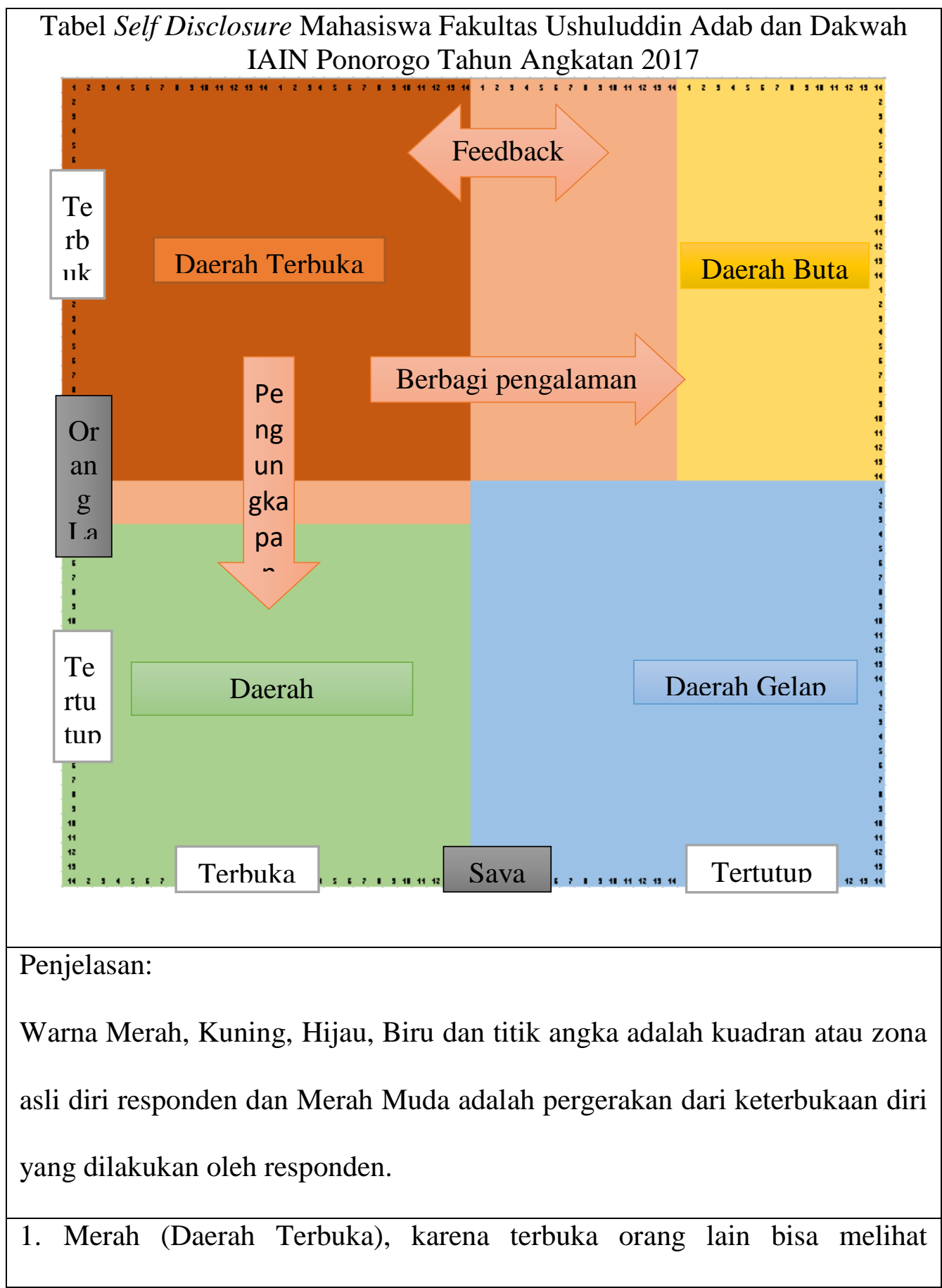


Whatsapp Stories Sebagai Media Komunikasi Self Disclosure (Studi pada Mahasiswa Fakultas Ushuluddin Adab dan Dakwah IAIN Ponorogo Tahun Angkatan 2017)

\section{Berliana Huaida}

responden dengan jelas, dan responden bisa melihat orang lain dengan jelas. Gambaran ini terlihat dari pertukaran nomor lalu saling menyimpan dan kemudian berbagi sebuah postingan. Pada daerah ini seluruh responden tetap mempertahankan daerah terbuka ini.

2. Kuning (Daerah Buta), disisi responden tertutup dari sisi orang lain terbuka. Dilihat dari postingan yang banyak merima masukan, respon, kritikan. Daerah buta ini terdapat campur tangan orang lain untuk menyingkap diri yang sebelumnya tidak diketahui. Caranya bisa dengan meminta saran agar daerah terbuka semakin lebar. Pada daerah ini seluruh responden pun berhasil membuka dan memperlebar daerah terbuka yang tergambarkan pergerakannya dengan disimbolkan warna merah muda.

3. Hijau (Daerah Tersembunyi), disisi responden terbuka dan disisi orang lain tertutup. Terlihat dari beberapa mahasiswa yang mengaku pernah mengemukakan sebuah rahasia dan yang bersifat privasi ke dalam postingannya, dan dari situlah orang lain menjadi tahu. Pada daerah ini Umi, Muiz, dan Maifir berhasil mempersempit daerah tersembunyi yang disimbolkan warna hijau dan memperlebar daerah terbuka dengan pergerakan yang disimbolkan warna merah muda. Sementara yang lainnya tetap mempertahankan daerah tersembunyi ini.

4. Hijau (Daerah Tersembunyi), disisi responden terbuka dan disisi orang lain tertutup. Terlihat dari beberapa mahasiswa yang mengaku pernah mengemukakan sebuah rahasia dan yang bersifat privasi ke dalam postingannya, dan dari situlah orang lain menjadi tahu. Pada daerah ini 
Umi, Muiz, dan Maifir berhasil mempersempit daerah tersembunyi yang disimbolkan warna hijau dan memperlebar daerah terbuka dengan pergerakan yang disimbolkan warna merah muda. Sementara yang lainnya tetap mempertahankan daerah tersembunyi ini.

5. Biru (Daerah Gelap), disisi responden tertutup dan dari sisi orang lain pun juga tertutup. Daerah ini hanya bisa dipecahkan dengan cara banyak berdiskusi, eksplorasi, observasi diri. Biasanya juga terungkap karena adanya sebuah tekanan. Pada daerah ini sebenarnya seluruh responden berpotensi memilikinya namun masih ragu untuk menyadarinya. Jadi daerah gelap ini tetap pada posisi awal yaitu tidak terbuka ataupun mengecil.

Berdasarkan pembahasan diatas, dapat simpulkan bahwa keterbukaan diri yang dilakukan oleh respoden Mahasiswa Fakultas Ushuluddin Adab dan Dakwah IAIN Ponorogo Tahun Angkatan 2017 yang termasuk kedalam empat Jendela Johari adalah Daerah Terbuka, Daerah Buta, dan Daerah Tertutup. Berikut gambaran besaran kuadran/jendela yang terbentuk: 
Whatsapp Stories Sebagai Media Komunikasi Self Disclosure (Studi pada Mahasiswa Fakultas Ushuluddin Adab dan Dakwah IAIN Ponorogo Tahun Angkatan 2017)

Berliana Huaida

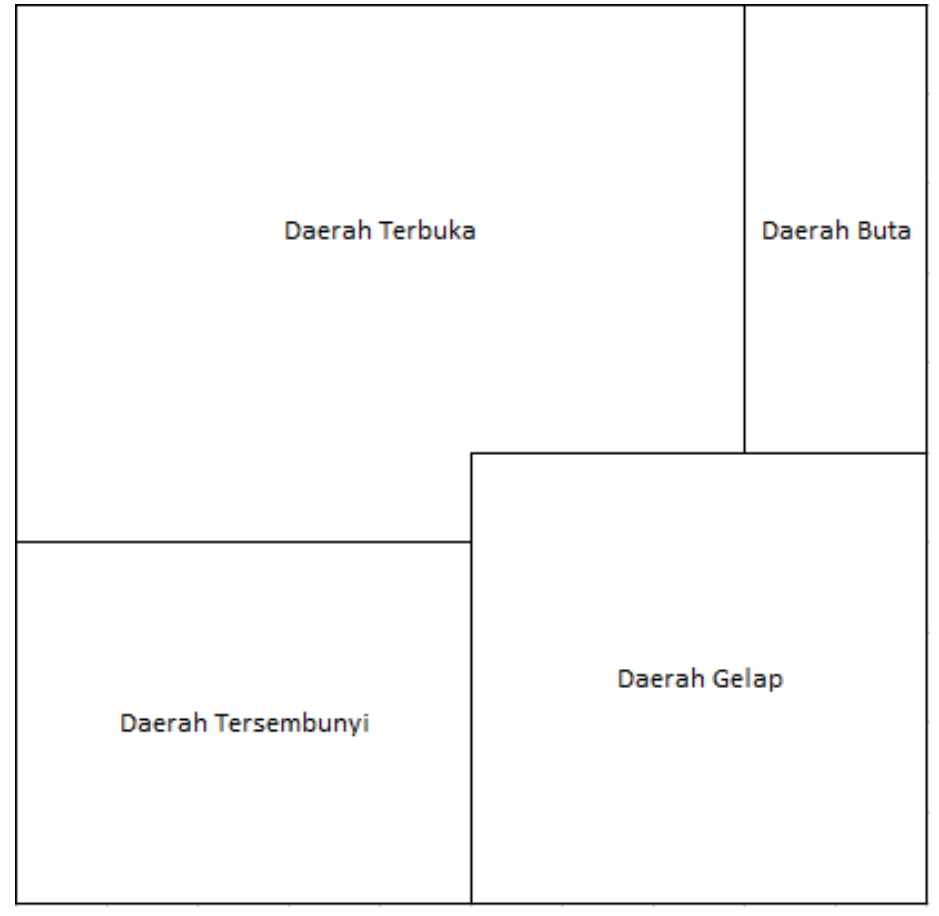

Gambar 4.2

Jendela Self Disclosure Mahasiswa Fakultas Ushuluddin Adab dan Dakwah IAIN

Ponorogo Tahun Angkatan 2017

Dapat dilihat dari gambar tersebut, bahwa Jendela Daerah terbuka memiliki ruang yang lebih besar dibandingkan dengan ketiga jendela lainnya. Dengan demikian, berarti self disclosure Mahasiswa Fakultas Ushuluddin Adab dan Dakwah IAIN Ponorogo Tahun Angkatan 2017 lebih banyak dilakukan dengan bentuk terbuka. Jika daerah terbuka lebih besar, dalam artian dalam memahami diri sendiri dan orang lain akan menghasilkan komunikasi yang baik. Walaupun mahasiswa melakukan keterbukaan diri secara terbuka namun tidak menutup kemungkinan bahwa mereka tetap menyaring apa yang akan ia tampilkan, tidak semuanya dapat diperlihatkan begitu saja.

Setiap jendela berbeda dengan orang lainnya, bergantung pada bagaimana orang tersebut berhubungan dengan orang lain. Menerapkan teori Johari Window dapat membantu kita untuk mendapatkan pemahaman dan meningkatkan hubungan. Pada saat menjumpai permasalahan yang jelas, kita tidak harus menyalahkan orang lain, sebaliknya kita harus tahu dan mengambil langkah-langkah untuk mengubah citra tersebut. Harus 
bersikap terbuka, berbagi, mendengarkan, dan memahami model Johari Window ini untuk komunikasi dan interaksi. (Paulus Kurniawan, 2017).

\section{B. Analisis Efek Komunikasi Self Disclosure Melalui Whatsapp Stories Yang Ditunjukkan Oleh Mahasiswa Fakultas Ushuluddin Adab dan Dakwah IAIN Ponorogo Tahun Angkatan 2017}

Media sosial dirancang untuk dapat menjangkau banyak orang dalam kalangan manapun. Berbagai informasi dapat dengan mudah didapatkan dalam waktu yang singkat. Oleh karena itu, media sosial dinilai memiliki banyak manfaatnya. Namun, jika penggunaannya tidak benar, akan menimbulkan opini publik yang nantinya akan menimbulkan kerugian banyak pihak.

Media sosial memiliki dampak yang cukup signifikan, dilihat dari segi positifnya adalah memudahkan pengguna untuk berinteraksi dengan banyak orang, menghilangkan hambatan jarak dan waktu, penyebaran informasi menjadi lebih cepat dan efesien. Namun media sosial juga memiliki sisi negatif yang mana dapat menyebabkan beberapa masalah, seperti masalah privasi, memungkinkan adanya konflik, menurunkan intensitas pertemuan dan lain-lain. Hal ini akan berlaku berbeda pada masing-masing pengguna yang tergantung pada kemampuan dalam kebijakan penggunaan media sosialnya. (Faisal Hidayat, 205).

Dalam konteks yang telah dilakukan peneliti terhadap responden, berikut merupakan analisis efek komunikasi self disclosure Mahasiswa Fakultas Ushuluddin Adab dan Dakwah IAIN Ponorogo Tahun Angkatan 2017:

\section{Efek Positif}

a. Mencapai kepuasan

Seluruh responden mengatakan bahwa setelah mereka membagikan sebuah postingan akan merasa lega, mengurangi rasa bosan, memiliki kebahagiaan tersendiri karena dapat menyampaikan apa yang ada dalam pikirannya, merasa memberikan 
Whatsapp Stories Sebagai Media Komunikasi Self Disclosure (Studi pada Mahasiswa Fakultas Ushuluddin Adab dan Dakwah IAIN Ponorogo Tahun Angkatan 2017)

Berliana Huaida

manfaat kepada orang lain karena informasi yang disampaikannya, bisa berbagi pengalaman, bisa menjadikan dirinya lebih dikenal orang lain, bisa memberikan penjelasan jika tidak mampu mengatakannya secara langsung.

b. Respon orang lain menentukan perubahan pada diri

1) Jika mendapatkan respon positif dari orang lain, responden merasa senang karena ter-apresiasi jadi postingannya tidak menjadi sia-sia, merasa ada yang sepemikiran dengannya, semakin bersemangat untuk memberikan atau membagikan postingan yang bersifat positif.

2) Jika mendapatkan respon negatif dari orang lain, responden memaklumi pemikiran orang lain, responnya akan tetap didengarkan lalu memperbaiki dan mengkoreksi/introspeksi diri apakah memang postingan tersebut megandung unsur negatif baru kemudian memberikan penjelasan.

c. Postingan orang lain membuka pikiran diri

1) Jika orang lain yang membagikan postingan positif, responden menganggap itu adalah hal baik, akan memberikan respon positif karena memberikan pengetahuan kepada orang lain, menjadi panutan diri untuk membuat dan membagikan postingan yang bersifat positif.

2) Jika ada orang lain yang membagikan potingan negatif, responden akan membiarkan dan melewatinya atau tidak melihatnya, tidak mengharapkan jika postingan negatif tersebut dibagikan, jika sempat pun pasti akan menegurnya.

3) Jika ada orang lain yang membuat postingan lebih banyak dari sendiri, responden menganggap itu adalah hal yang wajar karena itu merupakan keinginan dan kepuasannya, jika memiliki nilai manfaat pun akan mendapatkan apresiasi namun jika yang dipostingnya tidak bermanfaat akan diabaikan dan dilewati. 


\section{Efek Negatif}

Kurangnya kemampuan mengontrol pengunaan fitur whatsapp stories akan menimbulkan dampak apabila tidak dapat mengunakannya secara benar, seperti mendapatkan respon negatif dari orang lain, tidak mendapatkan kepercayaan, dan mendapatkan kerugian.

\section{Kesimpulan:}

Berdasarkan dari hasil penelitian dan pembahasan yang telah dilaksanakan melalui tahaptahap dengan metode kualitatif terhadap responden, maka peneliti dapat memaparkan kesimpulan sebagai berikut:

1. Bentuk komunikasi self disclosure yang ditunjukkan oleh Mahasiswa Fakultas Ushuluddin Adab dan Dakwah IAIN Ponorogo Tahun Angkatan 2017 Melalui Whatsapp Stories yang termasuk kedalam empat Jendela Johari adalah Daerah Terbuka, Daerah Buta, dan Daerah Tertutup. Keterbukaan diri yang berarti menginformasikan, membagi dan mengisahkan seseorang kepada orang lain baik itu berupa hal pribadi maupun umum. Curahan hati, kritikan, informasi pribadi, emosi/perasaan, itu sudah dikatakan sebagai keterbukaan diri, dan inilah yang telah ditunjukkan oleh seluruh responden.

Berdasarkan gambaran keterbukaan yang telah disesuaikan dengan empat jendela Johari, dapat diketahui bahwa Jendela Daerah terbuka memiliki ruang yang lebih besar dibandingkan dengan ketiga jendela lainnya. Dengan demikian, berarti self disclosure Mahasiswa Fakultas Ushuluddin Adab dan Dakwah IAIN Ponorogo Tahun Angkatan 2017 lebih banyak dilakukan dengan bentuk terbuka. Jika daerah terbuka lebih besar, dalam artian dalam memahami diri sendiri dan orang lain akan menghasilkan komunikasi yang baik. Walaupun mahasiswa melakukan keterbukaan diri secara terbuka namun tidak menutup 
Whatsapp Stories Sebagai Media Komunikasi Self Disclosure (Studi pada Mahasiswa Fakultas Ushuluddin Adab dan Dakwah IAIN Ponorogo Tahun Angkatan 2017)

Berliana Huaida

kemungkinan bahwa mereka tetap menyaring apa yang akan ia tampilkan, tidak semuanya dapat diperlihatkan begitu saja.

2. Efek komunikasi self disclosure yang ditunjukkan oleh Mahasiswa Fakultas Ushuluddin Adab dan Dakwah IAIN Ponorogo Tahun Angkatan 2017 Melalui Whatsapp Stories adalah berdampak positif dan negatif. Dilihat dari segi positifnya yaitu memudahkan pengguna untuk berinteraksi dengan banyak orang, menghilangkan hambatan jarak dan waktu, penyebaran informasi menjadi lebih cepat dan efesien. Namun media sosial juga memiliki sisi negatif yang mana dapat menyebabkan beberapa masalah, seperti masalah privasi, memungkinkan adanya konflik, menurunkan intensitas pertemuan dan lain-lain. Berikut adalah beberapa hasil dari analisis efek komunikasi tersebut:

a. Efek Positif:

1) Mencapai kepuasan, seperti perasaan lega dan bahagia karena dapat menyampaikan apa yang sedang difikirkannya serta dapat memberikan manfaat kepada orang lain.

2) Respon orang lain menentukan perubahan diri. Baik mendapatkan respon positif maupun respon negatif orang lain dapat memacu perubahan pada diri seseorang karena sebuah kritikan dan apresiasi begitu penting bagi kelancaran keterbukaan seseorang kedepannya.

3) Postingan orang lain membuka pikiran diri. Sebuah postingan orang lain baik itu positif maupun negatif dapat memacu diri untuk menerima dan mengikuti atau malah menolak dan membiarkannya.

b. Efek Negatif

Kurangnya kemampuan mengontrol pengunaan fitur whatsapp stories akan menimbulkan dampak apabila tidak dapat menggunakannya secara benar, seperti 
mendapatkan respon negatif dari orang lain, tidak mendapatkan kepercayaan, mendapatkan keuntungan atau kerugian.

\section{DAFTAR PUSTAKA}

Abidin, Yusuf Zainal. Manajemen Komunikasi Filosofi, Konsep, dan Aplikasi. Bandung: CV Pustaka Setia. 2015.

Hidayat, Faisal. Media Sosial, Identitas, Transformasi dan Tantangannya - Media Sosial Memborgol Milenial. Malang: Intelegensia Media. 2020.

Kurniawan, Paulus. Smart Leadership - Being A Leader. Yogyakarta: ANDI. 2017.

Semiawan, Conny R. Metode Penelitian Kualitatif . Jakarta: Grasindo. 2010.

Laili Humam Miftahudin, Ulama dan Media Sosial: Analisis Pesan Dakwah KH. Mustofa Bisri di Twitter, Muharrik: Jurnal Dakwah dan Sosial Vol.1 No. 2, 2018: 117-135. https://www.universitaspsikologi.com/2018/07/pengertian-selfdisclosure-membukadiri.html?m=1 diunduh pada tanggal 1 Desember 2020 pukul 12.06 wib https://www.whatsapp.com/about di unduh pada tanggal 8 desember 2019 pukul 15.47 wib. 